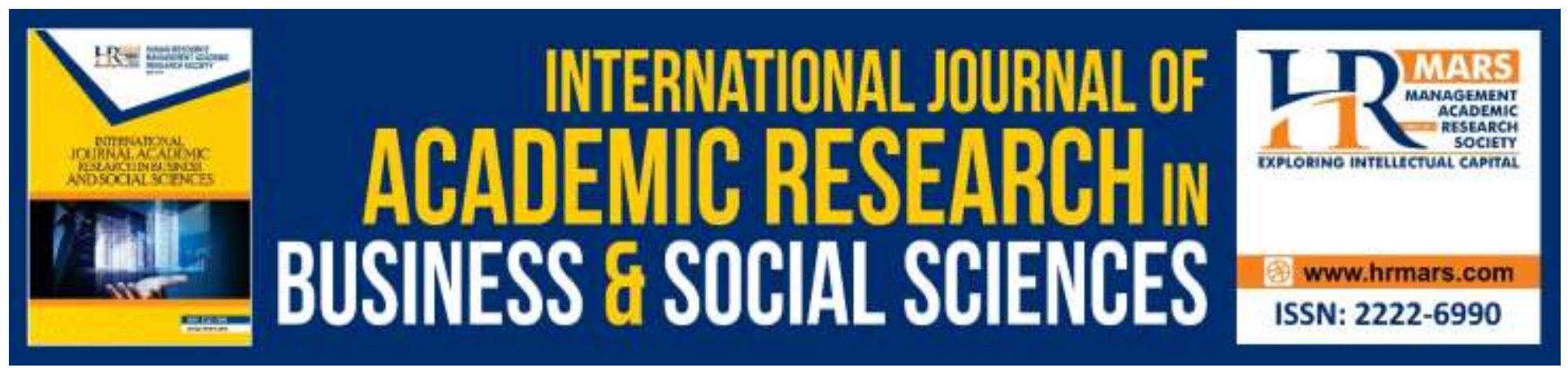

\title{
The Students' Beliefs on using Code-Switching in the ESL Classrooms
}

\section{Samihah Ab Razak \& Parilah M. Shah}

To Link this Article: http://dx.doi.org/10.6007/IJARBSS/v10-i2/6918

DOI:10.6007/IJARBSS/v10-i2/6918

Received: 02 January 2020, Revised: 28 January 2020, Accepted: 1 February 2020

Published Online: 18 February 2020

In-Text Citation: (Razak \& Shah, 2020)

To Cite this Article: Razak, S. A., \& Shah, P. M. (2020). The Students' Beliefs on using Code-Switching in the ESL Classrooms. International Journal of Academic Research in Business and Social Sciences, 10(2), 166-178.

Copyright: (C) 2020 The Author(s)

Published by Human Resource Management Academic Research Society (www.hrmars.com)

This article is published under the Creative Commons Attribution (CC BY 4.0) license. Anyone may reproduce, distribute, translate and create derivative works of this article (for both commercial and non-commercial purposes), subject to full attribution to the original publication and authors. The full terms of this license may be seen at: http://creativecommons.org/licences/by/4.0/legalcode

Vol. 10, No. 2, 2020, Pg. $166-178$

http://hrmars.com/index.php/pages/detail/IJARBSS

JOURNAL HOMEPAGE

Full Terms \& Conditions of access and use can be found at http://hrmars.com/index.php/pages/detail/publication-ethics 


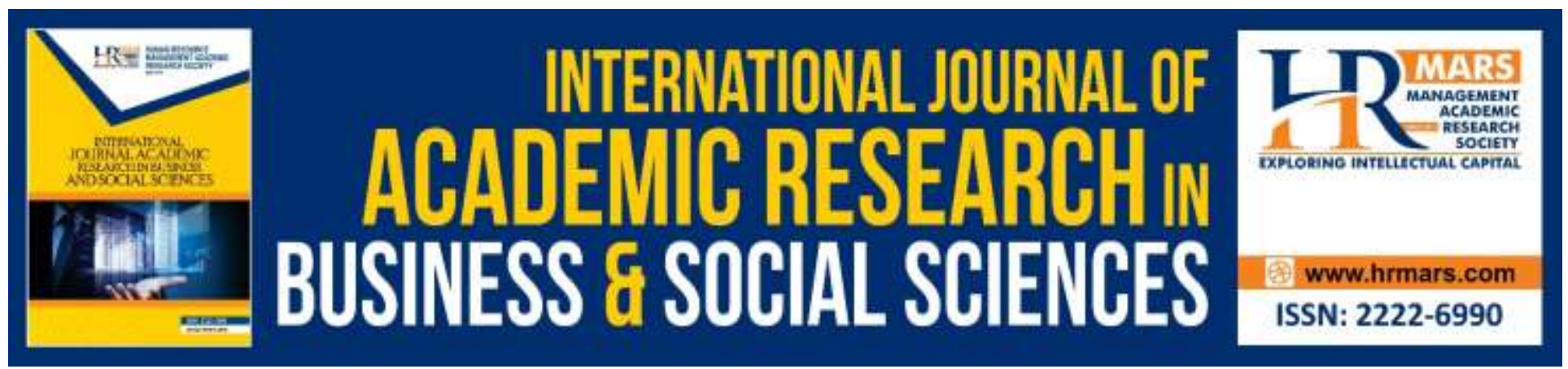

\title{
The Students' Beliefs on using Code-Switching in the ESL Classrooms
}

\author{
Samihah Ab Razak ${ }^{1,2}$ \& Parilah M. Shah ${ }^{2}$ \\ Sekolah Menengah Kebangsaan Seri Aman, 16800 Pasir Puteh, Kelantan, Malaysia ${ }^{1}$ \\ Universiti Kebangsaan Malaysia, 43600 Bangi, Selangor, Malaysia²
}

\begin{abstract}
The use of code-switching (CS) in English as Second Language (ESL) classrooms is an issue that has always been debated due to its pros and cons. This study aimed to identify the pre-university students' beliefs towards the use of CS in ESL classrooms. 91 pre-university students from a secondary school in Pasir Puteh, Kelantan participated in this study. This study employed a cross-sectional survey research design. The data were collected through the 19-item adapted questionnaire. Then, the frequency analysis via IBM SPSS Statistics Version 23 was performed to examine the students' responses. The finding revealed that the students had positively viewed the use of CS in ESL learning where CS was believed to be a beneficial tool during the lessons. Therefore, the finding may be useful to enlighten the policymakers, teachers and researchers on the issues that are related to the use of CS in ESL classrooms.
\end{abstract}

Keywords: Code-Switching (CS), ESL Classrooms, Students' Beliefs, Mother Tongue (L1), Second Language (L2)

\section{Introduction}

In 2018, only 25.54\% candidates of Malaysian University English Test (MUET), equivalent to IELTS (International English Language Testing System) November session managed to get at least band 4 where they would be considered as competent users (Malaysian Examinations Council 2018). The number equaled to only 17391 candidates out of 68094 who sat for MUET November session that year. This achievement was alarming since most of public universities and colleges in Malaysia use English as the medium of instruction. Thus, the low level of proficiency among the MUET candidates has brought about the need to deal with the issue. It is important in order to prepare the students not only for university life but also when they are entering the world of employment. One of the ways to address the issue is by code-switching (CS) during the teaching and learning process.

CS is one of the many issues concerning English as Second Language (ESL) learning that has been debated for decades. People are divided with this issue as it does have its pros and cons. CS is a common practice in bilingual or multilingual classrooms and this includes Malaysia. Malaysia is 
among the world's most multilingual countries, where many people can speak 3 or more languages fluently (Lew 2014). CS, also known as code shifting or language mixing is a term to describe the action of using two or more languages in the same utterance or conversation. It can be described as the inclusion of the mother tongue (L1) in a speech by the second language (L2) learners (Myers 2008).

The students' beliefs in using CS in ESL classrooms can also be linked to their learning strategy. Different students have different preferences on how to tackle their problems in language acquisition. Some students might choose CS to assist them in their linguistics hurdles. Some studies have proven that CS can be useful during the teaching and learning process. The studies conducted by Badrul and Kamaruzaman (2009), Adibah (2016) and Nurhamidah et al. (2018) revealed that the students, especially the weak students prefer CS to help them in the learning process. This strategy can assist the students to have a better understanding of the discourse, grammar and content learnt.

However, some studies show some opposing views on using CS. Some studies revealed that CS could affect the students' language proficiency and their confidence in speaking English (Aljoundi 2013; Mokgwathi \& Webb 2013). The abuse use of CS can make the students overreliance on their L1. This can eventually hinder the objective of learning the L2 and eventually affect their language acquisition. Thus, research on students' beliefs is important to give awareness to the teachers about language learning from the students' perspectives. Besides, it can also help the students to identify the best strategy that suits them to improve their language acquisition.

Therefore, this study aims to investigate the pre-university students' beliefs towards CS in ESL learning at Sekolah Menengah Kebangsaan Seri Aman in Pasir Puteh, Kelantan.

\section{Literature Review}

According to Valdes-Fallis (1978), the action of using two languages alternately in terms of word, phrase, clause or sentence level is known as code-switching. Similarly, Musyken (1995) denoted CS as the use of more than one language in the same conversation. Besides, CS is a linguistic term to define the inclusion of L1 in a speech by L2 learners (Myers, 2008). In other words, CS is the action of using two or more languages in the same utterance or conversation that involves the switches between languages at clause or sentence boundaries.

The use of CS has been debated for many years and it is a common phenomenon among the bilinguals and multilingual users. These users usually code switch to express themselves and also for their personal intentions. Besides, it is also used to build interpersonal relationships among the members in the same community (Sert, 2005). It can be perceived as a tool to create linguistic solidarity among the people from the same ethnics and cultures.

In Malaysian ESL classrooms, the teachers usually code switch for many purposes especially for academic purposes but, sometimes there is an occasion where they use CS unconsciously. Even though it is performed unconsciously, it can be beneficial in the language learning environment. Many studies have been conducted to investigate the teachers' use of CS in ESL classrooms (Badrul \& Kamaruzaman, 2009; Dykhanova, 2015; Joanna, 2014). The teachers usually use CS to explain the 
difficult words, terms and grammar to the students, so they will have a better understanding of the lessons. This is in line with the study by Tibategeza and Plessis (2018) who revealed that the students learnt better using the language that they understood.

In addition, CS is also used to reduce the students' affective filters such as anxiety, afraid and demotivated. According to Krashen Affective Filter Hypothesis (1985), reducing the students' affective filter can ensure the success of language acquisition. The teachers also code switch in ESL classrooms to clarify meaning by repeating the words and instruction using the students' mother tongue. However, this repetitiveness may lower the students' motivation to learn the target language as they know the instruction will be followed in their L1, thus may negatively affect their English proficiency level.

On the other hand, the students use CS in ESL classrooms to help them understand the lesson better. As English is not their native language, the students might face linguistics hurdles during the process. CS can be considered as one of the language strategies by the students to fill the gap, so the successful learning can be ensured. There are many studies have been carried out to identify the students' perceptions and beliefs on the use of CS (Debreli \& Oyman, 2016; Adibah, 2016; Nurhamidah et al. 2018). Besides, Malaysian students are usually bilinguals and multilingual. So, it is a norm for them to bring their L1 acquisition and prior knowledge to assist them in L2 learning. The students also code switch to communicate with their peers as they will be more comfortable to communicate using a language that they both shares. However, the reliance on L1 should be limited as many students nowadays whose English is not their native language are learning English, instead of learning in English. This is worrisome as this will give negative effects on their proficiency in English and this will eventually affect their employment or performance in the future.

\section{Methodology}

This study employed a cross-sectional survey design, one of the procedures in quantitative research. This design was chosen because it allowed the researcher to collect the data from the research participants at one point in times. So, it was convenient and suitable for this study.

The study was conducted at Sekolah Menengah Kebangsaan Seri Aman, a secondary school in Pasir Puteh, Kelantan. It was located in a rural area with 1079 enrolled students with 101 teachers. The simple random sampling was used when selecting the participants. So, all the members in the population would get an equal chance to be included in the sample (Bryman, 2012). 91 upper preuniversity students from the school voluntarily participated in this study.

Furthermore, for the research instrument, this study administered a questionnaire to the participants to collect the data. The questionnaire was adapted from a study by Joanna (2014) on CS in Malaysian ESL classroom. This 19-item questionnaire used a 5-point Likert scale namely strongly disagree, disagree, neutral, agree and strongly agree, in an effort to extract specific responses from the participants regarding the issue. It was divided into two sections, where Section A was on the participant's biographical information and Section B on the participant's beliefs of using CS in ESL learning. Besides, the questionnaire was also prepared in two languages; Malay and English in order 
INTERNATIONAL JOURNAL OF ACADEMIC RESEARCH IN BUSINESS AND SOCIAL SCIENCES Vol. 10, No. 2, Feb, 2020, E-ISSN: 2222-6990 ¿ 2020 HRMARS

to help the low-level proficiency students to have a better understanding of the statement in each item.

Before that, the pilot test was conducted for the questionnaire where 26 students participated in the test. Based on the students' responses and feedbacks, some necessary amendments were made to the questionnaire. After obtaining the approval from the school administrators and the participants, the questionnaire was distributed. The participants were given a brief explanation of the procedure in order to avoid any confusion. They completed the questionnaire during the lesson under the supervision of the researcher. Data collected were then analysed using frequency analysis via IBM SPSS Statistics Version 23.

\section{Results}

\section{Participants' Biographical Information}

The participants from this study were pre-university students from Sekolah Menengah Kebangsaan Seri Aman, Pasir Puteh, Kelantan. 91 participants had taken part in this study where it consisted of 41 males (45.1\%) and 50 females (54.9\%). From the data collected, the majority of the participants, comprised of 90 of them were Malay (98.9\%), while only one participant from other race namely Siamese (1.1\%).

Out of 91 participants, 2 of them (2.2\%) got grade A for English papers in their SPM. There were 16 participants (17.6\%) who got grade B and 19 participants (20.9\%) for grade C. Almost half of the overall participants, 42 of them (46.2\%) obtained grade D for their English papers in SPM. Besides, 7 of the participants (7.7\%) from this study scored $E$ and 5 of them (5.5\%) failed their English papers.

Furthermore, the participants were asked to rank their level of English. More than half of them, consisting of 64 participants (70.3\%) felt that their level of English was okay and 7 participants (7.7\%) ranked theirs as good. In addition, from the data collected, 17 participants $(18.7 \%)$ considered them as weak in English, while 3 of them (3.3\%) felt their level of English was very weak.

\section{Students' Beliefs towards CS in ESL Classrooms}

To answer the question; 'What are the students' beliefs towards CS in ESL learning?' the data collected were analyzed using frequencies in the form of a percentage. After that, the average percentage was calculated in order to determine the students' beliefs on the issue discussed, either it was positive or negative.

Based on the data presented in Table 1, more than half of the participants were in agreement that the use of CS by their teachers makes the English lessons more gratifying. The number was made up of $71.4 \%$ of the whole participants in this study. However, $8.8 \%$ of the participants reported that using CS had no impact in making the English lessons more entertaining, while $19.8 \%$ of them remained impartial with the statement. 
INTERNATIONAL JOURNAL OF ACADEMIC RESEARCH IN BUSINESS AND SOCIAL SCIENCES Vol. 10, No. 2, Feb, 2020, E-ISSN: 2222-6990 @ 2020 HRMARS

\begin{tabular}{ccccc}
\hline $\begin{array}{c}\text { Strongly } \\
\text { Disagree }\end{array}$ & Disagree & Neutral & Agree & $\begin{array}{c}\text { Strongly } \\
\text { Agree }\end{array}$ \\
\hline $2.2 \%$ & $6.6 \%$ & $19.8 \%$ & $52.7 \%$ & $18.7 \%$ \\
\hline
\end{tabular}

Table 1: Using CS to make the lesson more enjoyable

Table 2 showed the data that had been collected for using CS in enhancing the participants' understanding during the ESL classrooms. Majority of them constituted $77 \%$ were in consensus that the use of CS did help them to enhance their comprehension during the ESL classrooms. On the other hand, only 3.3\% of the participants stated using CS had no effect on their understanding of the English lessons, whereas $19.8 \%$ of them stayed neutral on this issue.

\begin{tabular}{ccccc}
\hline $\begin{array}{c}\text { Strongly } \\
\text { Disagree }\end{array}$ & Disagree & Neutral & Agree & $\begin{array}{c}\text { Strongly } \\
\text { Agree }\end{array}$ \\
\hline 0 & $3.3 \%$ & $19.8 \%$ & $41.8 \%$ & $35.2 \%$ \\
\hline
\end{tabular}

Table 2: Using CS for the students' better understanding

As evident from the data shown in Table 3, the use of CS did play a role in building up the participants' confidence and motivation to learn English. $66 \%$ of the participants in this study agreed their confidence, as well as motivation levels, were elevated when CS was used during ESL classrooms. Nevertheless, $11 \%$ of the participants reported that using CS in the lessons by the teachers did not affect their confidence and motivation levels to learn English. Meanwhile, 23.1\% of them remained undecided with this matter.

\begin{tabular}{ccccc}
\hline $\begin{array}{c}\text { Strongly } \\
\text { Disagree }\end{array}$ & Disagree & Neutral & Agree & $\begin{array}{c}\text { Strongly } \\
\text { Agree }\end{array}$ \\
\hline $3.3 \%$ & $7.7 \%$ & $23.1 \%$ & $37.4 \%$ & $28.6 \%$ \\
\hline
\end{tabular}

Table 3: Using CS to increase the students' confidence and motivation levels

The results in Table 4 suggested that the participants would pay more attention in ESL classrooms with the use of CS without feeling anxious about unfamiliar L2 words. Most of the participants, $74.8 \%$ believed they could concentrate on the lessons more if CS was used to explain unfamiliar L2 words and sentences. On the other hand, 9.9\% of the participants failed to agree that using CS had ever achieved this purpose, whereas $15.4 \%$ of them were ambivalent with this issue.

\begin{tabular}{ccccc}
\hline $\begin{array}{c}\text { Strongly } \\
\text { Disagree }\end{array}$ & Disagree & Neutral & Agree & $\begin{array}{c}\text { Strongly } \\
\text { Agree }\end{array}$ \\
\hline $2.2 \%$ & $7.7 \%$ & $15.4 \%$ & $48.4 \%$ & $26.4 \%$ \\
\hline
\end{tabular}

Table 4: Using CS to help the students' to stay focused on the lesson

The data collected in Table 5 proposed that using CS influenced the participants to be active during the activities in the English lessons. It was revealed that $73.6 \%$ of the participants were in consensus as they felt more engaged in the lessons when CS was used. However, there were a small 
INTERNATIONAL JOURNAL OF ACADEMIC RESEARCH IN BUSINESS AND SOCIAL SCIENCES Vol. 10, No. 2, Feb, 2020, E-ISSN: 2222-6990 @ 2020 HRMARS

number of participants who disagreed. It was evident when only $2.2 \%$ of them went against this motion. Another $24.2 \%$ of the participants remained indecisive with the statement.

\begin{tabular}{ccccc}
\hline $\begin{array}{c}\text { Strongly } \\
\text { Disagree }\end{array}$ & Disagree & Neutral & Agree & $\begin{array}{c}\text { Strongly } \\
\text { Agree }\end{array}$ \\
\hline $1.1 \%$ & $1.1 \%$ & $24.2 \%$ & $52.7 \%$ & $20.9 \%$ \\
\hline
\end{tabular}

Table 5: Using CS increases the students' engagement in the lessons

Based on the findings presented in Table 6, most of the participants, $42.9 \%$ were on the fence regarding the issue of conducting the lessons entirely in English. Nevertheless, 36.3\% of the participants did not believe it was the best option for the teachers to use English as the sole language of instruction in ESL classrooms. Meanwhile, 20.9\% of them preferred the lessons to be free from the use of CS.

\begin{tabular}{ccccc}
\hline $\begin{array}{c}\text { Strongly } \\
\text { Disagree }\end{array}$ & Disagree & Neutral & Agree & $\begin{array}{c}\text { Strongly } \\
\text { Agree }\end{array}$ \\
\hline $7.7 \%$ & $28.6 \%$ & $42.9 \%$ & $17.6 \%$ & $3.3 \%$ \\
\hline
\end{tabular}

Table 6: Using English entirely in the lessons

From the data shown in Table 7, it showed that the participants preferred the minimal use of CS in the ESL classrooms. $41.8 \%$ of the participants were in agreement that the less use of CS in the English lessons would be the best option. On the other hand, $27.5 \%$ of the participants wanted the teachers to use CS when conducting the English lessons, while $30.8 \%$ of them were still impartial with this matter.

\begin{tabular}{ccccc}
\hline $\begin{array}{c}\text { Strongly } \\
\text { Disagree }\end{array}$ & Disagree & Neutral & Agree & $\begin{array}{c}\text { Strongly } \\
\text { Agree }\end{array}$ \\
\hline $4.4 \%$ & $23.1 \%$ & $30.8 \%$ & $34.1 \%$ & $7.7 \%$ \\
\hline
\end{tabular}

Table 7: Minimizing the use of CS in the lessons

The results in Table 8 suggested that the participants leaned towards the mixing of English and their L1in ESL classrooms. It was evident when the majority of the participants, $82.5 \%$ had a strong inclination to use CS during the English lessons. Meanwhile, $15.4 \%$ of them remained undecided and only a small number of the participants, $2.2 \%$ were against the use of CS during the ESL classrooms.

\begin{tabular}{ccccc}
\hline $\begin{array}{c}\text { Strongly } \\
\text { Disagree }\end{array}$ & Disagree & Neutral & Agree & $\begin{array}{c}\text { Strongly } \\
\text { Agree }\end{array}$ \\
\hline $1.1 \%$ & $1.1 \%$ & $15.4 \%$ & $36.3 \%$ & $46.2 \%$ \\
\hline
\end{tabular}

Table 8: Mixing English and other languages during the lessons

As shown by the data in Table 9, $44.0 \%$ of the participants were indecisive either to use a language other than English or not in ESL classrooms. On the other hand, $18.7 \%$ of the participants 
INTERNATIONAL JOURNAL OF ACADEMIC RESEARCH IN BUSINESS AND SOCIAL SCIENCES Vol. 10, No. 2, Feb, 2020, E-ISSN: 2222-6990 @ 2020 HRMARS

showed support by disapproving the use of other languages except for English during the lessons. Meanwhile, $37.4 \%$ of them did believe including other languages in the English lessons would be better.

\begin{tabular}{ccccc}
\hline $\begin{array}{c}\text { Strongly } \\
\text { Disagree }\end{array}$ & Disagree & Neutral & Agree & $\begin{array}{c}\text { Strongly } \\
\text { Agree }\end{array}$ \\
\hline $9.9 \%$ & $27.5 \%$ & $44.0 \%$ & $12.1 \%$ & $6.6 \%$ \\
\hline
\end{tabular}

Table 9: Disapproval of using other languages in the English lessons

It was apparent from the findings presented in Table 10 that the participants were having troubles in their English lessons when CS was not used. $60.5 \%$ of the participants faced problems in their learning if the teachers did not provide any explanation in their L1 during the English lessons. On the contrary, $14.3 \%$ of the participants indicated that they had no trouble if CS was not used during the English lessons, while $25.3 \%$ of them remained in the middle with the issue.

\begin{tabular}{ccccc}
\hline $\begin{array}{c}\text { Strongly } \\
\text { Disagree }\end{array}$ & Disagree & Neutral & Agree & $\begin{array}{c}\text { Strongly } \\
\text { Agree }\end{array}$ \\
\hline $4.4 \%$ & $9.9 \%$ & $25.3 \%$ & $42.9 \%$ & $17.6 \%$ \\
\hline
\end{tabular}

Table 10: Difficulty to learn when CS was not used

The data presented in Table 11 proposed that the participants had mixing views on using CS to sustain their attention in the ESL classrooms. From the findings, $48.4 \%$ of the participants admitted that they faced difficulty to focus on the English lessons if the teachers opted to use only English. Meanwhile, $30.8 \%$ of the participants had no problem if CS was not used, whereas, $20.9 \%$ were ambivalent regarding this matter.

\begin{tabular}{ccccc}
\hline $\begin{array}{c}\text { Strongly } \\
\text { Disagree }\end{array}$ & Disagree & Neutral & Agree & $\begin{array}{c}\text { Strongly } \\
\text { Agree }\end{array}$ \\
\hline $4.4 \%$ & $26.4 \%$ & $20.9 \%$ & $36.3 \%$ & $12.1 \%$ \\
\hline
\end{tabular}

Table 11: Difficulty to concentrate when CS was not used

As evident from the data presented in Table 12, the participants used CS if they needed to share and express their opinions in English. 75.9\% of the participants were in consensus that CS was opted if they were having trouble in expressing themselves. On the other hand, $8.8 \%$ of the participants did not rely on CS in sharing their views during the English lessons, while $15.4 \%$ of them were still on the fence regarding the matter.

\begin{tabular}{ccccc}
\hline $\begin{array}{c}\text { Strongly } \\
\text { Disagree }\end{array}$ & Disagree & Neutral & Agree & $\begin{array}{c}\text { Strongly } \\
\text { Agree }\end{array}$ \\
\hline $1.1 \%$ & $7.7 \%$ & $15.4 \%$ & $47.3 \%$ & $28.6 \%$ \\
\hline
\end{tabular}

Table 12: Using CS to express oneself 
INTERNATIONAL JOURNAL OF ACADEMIC RESEARCH IN BUSINESS AND SOCIAL SCIENCES Vol. 10, No. 2, Feb, 2020, E-ISSN: 2222-6990 @ 2020 HRMARS

Based on the results shown in Table 13, the participants tended to use CS when they were trying to have a smooth flow of a conversation. $59.4 \%$ of the participants chose to use CS to communicate with other people during English lessons. From the table, only a small number of the participants, $6.6 \%$ did not opt to CS when communicating with others. Meanwhile, $34.1 \%$ of them remained undecided with the statement.

\begin{tabular}{ccccc}
\hline $\begin{array}{c}\text { Strongly } \\
\text { Disagree }\end{array}$ & Disagree & Neutral & Agree & $\begin{array}{c}\text { Strongly } \\
\text { Agree }\end{array}$ \\
\hline $2.2 \%$ & $4.4 \%$ & $34.1 \%$ & $41.8 \%$ & $17.6 \%$ \\
\hline
\end{tabular}

Table 13: Using CS for communication purposes

From the data presented in Table 14, the participants were comfortable to use CS during the English lessons when conversing with their friends who speak the same L1. The number, made up 72.6\% of the whole participants in this study suggested that the participants chose to use CS when they spoke to their friends. In contrast, only $5.5 \%$ of them believed using CS was not the best option in such situations, whereas $22.0 \%$ of the participants stayed impartial with this issue.

\begin{tabular}{ccccc}
\hline $\begin{array}{c}\text { Strongly } \\
\text { Disagree }\end{array}$ & Disagree & Neutral & Agree & $\begin{array}{c}\text { Strongly } \\
\text { Agree }\end{array}$ \\
\hline 0 & $5.5 \%$ & $22.0 \%$ & $38.5 \%$ & $34.1 \%$ \\
\hline
\end{tabular}

Table 14: Using CS when conversing with peers who share the same L1

The findings shown in Table 15 suggested that the participants chose to use CS when they could not explain difficult words to their peers during the English lessons. It was evident when $77.0 \%$ of the participants were in agreement that using CS was necessary if it could help them to give a better explanation of the difficult words in the ESL classrooms. Conversely, $5.5 \%$ of the participants opted not to use CS to perform this task, while $17.6 \%$ of them remained irresolute with this matter.

\begin{tabular}{ccccc}
\hline $\begin{array}{c}\text { Strongly } \\
\text { Disagree }\end{array}$ & Disagree & Neutral & Agree & $\begin{array}{c}\text { Strongly } \\
\text { Agree }\end{array}$ \\
\hline 0 & $5.5 \%$ & $17.6 \%$ & $35.2 \%$ & $41.8 \%$ \\
\hline
\end{tabular}

Table 15: Using CS to explain difficult words to peers

Based on the data collected from the distributed questionnaire, the students' beliefs on integrating CS in the English lessons could be categorized into two groups. The first group was the students' positive views on using CS in the ESL classrooms and the other group was the students' negative views. Table 16 revealed the percentages of the participants' responses for each statement regarding the issue discussed. The percentages were the cumulative percentages for the responses ranked of 4 and 5 on the Likert scale in the questionnaire namely, agree $=4$ and strongly agree $=5$.

After that, all the percentages from each group were calculated to find the average in order to find the students' beliefs on the use of CS, either it was positive or negative. As shown in Table 16, the majority of the participants in this study had viewed the use of CS in ESL classrooms positively. It 
INTERNATIONAL JOURNAL OF ACADEMIC RESEARCH IN BUSINESS AND SOCIAL SCIENCES Vol. 10, No. 2, Feb, 2020, E-ISSN: 2222-6990 @ 2020 HRMARS

was evident when the average percentage of the participants who believed CS could assist them in learning English was 69.9\%. Roughly, this percentage made up of 64 out of 91 participants in this study. On the contrary, only a small number of participants accounted for $27.1 \%$ had negative views on the practice of CS during the English lessons. They had expressed their hope for the teachers to minimise or lessen the use of other languages in the ESL classrooms.

\begin{tabular}{lc}
\hline \multicolumn{2}{c}{ Students' Positive Views } \\
\hline Using CS to make the lesson enjoyable & $71.4 \%$ \\
Using CS for the students' better understanding & $77.0 \%$ \\
Using CS to increase the students' confidence and motivation levels & $66.0 \%$ \\
Using CS to help the students to stay focused on the lesson & $74.8 \%$ \\
Using CS increases the students' engagement in the lessons & $73.6 \%$ \\
Mixing English and other languages during the lessons & $82.5 \%$ \\
Difficulty to learn when CS was not used & $60.5 \%$ \\
Difficulty to concentrate when CS was not used & $48.4 \%$ \\
Using CS to express oneself & $75.9 \%$ \\
Using CS for communication purposes & $59.4 \%$ \\
Using CS when conversing with peers who share the same L1 & $72.6 \%$ \\
Using CS to explain difficult words to peers & $77.0 \%$ \\
\hline \multicolumn{2}{c}{ Students' Negative Views } \\
\hline \multicolumn{2}{c}{ Average } \\
\hline Using English entirely in the lessons & $69.9 \%$ \\
\hline Minimizing the use of CS in the lessons & $20.9 \%$ \\
Disapproval of using other languages in the English lessons & $41.8 \%$ \\
\hline
\end{tabular}

Table 16: Summary of the students' beliefs on the use of CS in ESL classrooms

Thus, from the findings of this study, it can be concluded that the students' had positive views towards the use of CS in the ESL classrooms. It is evident as the students believed the use of CS can assist them during the English lessons. The findings of this study concurred with the findings from previous studies by Joanna (2014), Adibah (2016) and Nurhamidah et al. (2018) who agreed CS could be beneficial to the students in ESL learning. Furthermore, the students were in consensus that when CS was used, the lessons would be more enjoyable and comprehensible. In addition, they were also more confident and motivated to learn in the class which practiced CS, instead of English only medium. These positive feelings indicated that CS provided a supportive language environment for second language learners. These findings regarding the affective supports were in line with the findings found in the studies by Joanna (2014), Mazlin (2015) and Memon et al. (2016).

Besides, the students perceived CS as one of the indicators for their active participation and being more focused during the English lessons. These findings were supported by the study from Badrul, \& Kamaruzaman (2009) where CS promoted the students' engagement during the English lessons. This was due to the fact that the students were comfortable and felt supported by the learning environment as CS acted as a bridge to connect the teachers to the students. By using CS, 
the teachers and the students would be able to discuss any issue without worrying about the problems that may arise due to the students' limited proficiency. Hence, they would feel less stressed or anxious during English lessons. This statement could be related to Krashen's Affective Filter hypothesis where reducing the students' affective filters could help the students to perform better in their second language acquisition process. In addition, it can be perceived that the use of CS is one of the most preferred strategies by the students to learn English. It is understandable as most of the Malaysian students can be considered bilinguals or multilingual, hence they will use their acquisition in L1 to tackle the linguistics hurdles that they may face.

However, the findings also showed that some participants hope for minimizing the use of CS in ESL classrooms. Although there was only a small fraction of them, their view on the use of CS should not be ignored. It is because the overreliance on the L1 can hinder the purpose of learning the target language. This negative view may stem from the students' lack of exposure to the target language. The only possible way to learn it is in the classroom, thus leading them to oppose the idea of using too much L1 during the lessons. Besides, there is also a possibility that the students' different level of proficiency affects their view on the use of CS as revealed by the studies from Debreli and Oyman (2016) and Khati (2011). However, this study does not look at the students' proficiency level with regards to the use of CS, so it is impossible to draw any conclusion between these two.

\section{Conclusion}

Overall, this study revealed that the students had viewed the use of CS in ESL classrooms in Malaysia positively where its use as one of the strategies to acquire the target language should be embraced. Hence, the study has proposed some implications to several parties that involve in education field. Firstly, for language policymakers, the finding of this study should be taken into consideration when designing the language policy. It is because the majority of the students agreed with the positive contribution of CS to ESL learning. Thus, the English-only policy should be reexamined to suit the different needs of the students. By taking into account the students' perceptions and beliefs on the use of CS, the examined curriculum might probably have more positive impacts on the students' second language fluency instead of monolingual practices. The students' needs should be the main focus as they are one of the parties that will be directly impacted by any changes made by the higher ups.

Besides, for the teachers, they should be more open with the use of CS in ESL classrooms. It should be considered that it is not wrong to use CS to attend to the students' need especially the weak ones. So, the teachers should stop the negative sentiment that CS can affect the students' second language development. Together with this, the unspoken rule of forbidding the students to use their L1 during the English lessons should also be put an end to. It should be remembered that the learning will not be successful if the students learn nothing from the lessons.

Lastly, for the researchers, this study is only restricted to one school in Pasir Puteh, Kelantan with only 91 participants. So, the finding cannot be reflected and generalized to other secondary schools in Kelantan and also Malaysia. A nationwide survey is recommended to identify the Malaysian students' beliefs on the use of CS in ESL classrooms. Thus, thorough preparation from the future 
INTERNATIONAL JOURNAL OF ACADEMIC RESEARCH IN BUSINESS AND SOCIAL SCIENCES

Vol. 10, No. 2, Feb, 2020, E-ISSN: 2222-6990 @ 2020 HRMARS

researchers is needed in terms of times, cost and target population. Hopefully, this study can shed some lights in assisting the students to successfully learn and master the target language, especially in Malaysian education settings.

\section{Acknowledgements}

First and foremost, I am very grateful to all the people from Faculty of Education, Universiti Kebangsaan Malaysia for helping me during this research. Besides, my deepest appreciation towards the principal, teachers and students from Sekolah Menengah Kebangsaan Seri Aman, Pasir Puteh, Kelantan for their willingness to participate in this research. I am thankful with their warmth support and this study would not be possibly completed without them. Lastly, I wish to express my gratitude to my beloved parents and family members for their understanding, encouragement and endless support.

\section{Corresponding Author}

Parilah M. Shah Faculty of Education, Universiti Kebangsaan Malaysia, 43600 Bangi, Selangor, Malaysia

Email: drparila@gmail.com

\section{References}

Aljoundi, E. K. (2013). The Strengths and Weaknesses of Code Switching and Bilingualism in the Language Classroom. 10.13140/RG.2.1.5051.1762

Badrul, H. A., \& Kamaruzaman, J. (2009). Teachers' Code-Switching in Classroom Instructions for Low English Proficient Learners. English Language Teaching 2(2): 49-55.

Bryman, A. (2012). Social Research Method. Fourth Edition. New York: Oxford University Press Inc.

Debreli, E., \& Oyman, N. (2016). Students' Preferences on the Use of Mother Tongue in English as a Foreign Language Classrooms: Is It the Time to Re-examine English-only Policies? English Language Teaching 9(1): 148-162.

Dykhanova, A. (2015). Functions of Code-Switching and Attitudes toward Them: A Case Study (master's thesis). Eastern Mediterranean University, Gazimağusa, North Cyprus.

Joanna, T. S. (2014). Code Switching in the Malaysian ESL Classroom (master's thesis). University of Otago, Dunedin, New Zealand.

Khati, A. R. (2011). When and Why of Mother Tongue Use in English Classrooms. Journal of Nepal English Language Teachers' Association 16(1-2): 42-51.

Lew, J. (2014). 9 of the World's Most Multilingual Countries. Retrieved from https://www.mnn.com/lifestyle/arts-culture/stories/9-of-the-worlds-most-multilingualcountries

Mazlin, M. M. (2015). Lecturers' and Students' Beliefs in Code-Switching: A Malaysian Polytechnic Context. TEFLIN Journal 26(1): 85-96.

Memon, N., Altaf, S., \& Khuwaja, N. A. (2016). The Functions of Code Switching in ESL Classrooms of Sindh University Nazish. International Research Journal of Arts and Humanities 101-106.

Mokgwathi, T., \& Webb, V. (2013). The Educational Effects of Code-Switching in the 
INTERNATIONAL JOURNAL OF ACADEMIC RESEARCH IN BUSINESS AND SOCIAL SCIENCES

Vol. 10, No. 2, Feb, 2020, E-ISSN: 2222-6990 @ 2020 HRMARS

Classroom - Benefits and Setbacks: A Case of Selected Senior Secondary Schools in Botswana. Studies in the Languages of Africa 44(3): 108-125.

https://doi.org/10.1080/10228195.2013.839734

Myers, M. J. (2008). Code Switching in Content Learning. DIm. Wilkinson, R., \& Zegers, V. (pnyt.) Realizing Content and Language Integration in Higher Education, hlm. 43-48.

Adibah, N. Z. (2016). Code Switching in the Malaysian ESL Classroom: Learners' Attitudes and Development of Language Proficiency (master's thesis). Universiti Teknologi MARA.

Nurhamidah, Fauziati, E. \& Supriyadi, S. (2018). Code-Switching in EFL Classroom: Is It Good or Bad? Journal of English Education 3(2): 78-88. http://dx.doi.org/10.31327/jee.v3i2.861

Sert, O. (2005). The Functions of Code Switching in ELT Classrooms. The Internet TESL Journal 8(8). Retrieved from http://iteslj.org/Articles/Sert-CodeSwitching.html

Tibategeza, E. R., \& Plessis, T. (2018). The Prospects of Kiswahili as a Medium of Instruction in the Tanzanian Education and Training Policy. Journal of Language and Education 4(3): 88-98. 10.17323/2411-7390-2018-4-3-88-98

Valdes-Fallis, G. (1978). Code Switching and the Classroom Teacher, Language in Education: Theory and Practice, No. 4. Virginia: Center for Applied Linguistics. 